\title{
The Implementation of Inclusive Islamic Religion Education in Sibolga State Senior High School
}

\author{
Hasan Asari ${ }^{1}$, Abd Mukti1 \& Sapirin ${ }^{2 *}$ \\ 1 Postgraduate of Universitas Islam Negeri Sumatera Utara, Medan, Indonesia \\ 2 Doctoral Student of Universitas Islam Negeri Sumatera Utara, Medan, Indonesia \\ *Corresponding Author: sapirinnasution@gmail.com
}

\begin{abstract}
This study reveals about the factors regarding the implementation of inclusive Islamic religious education in Senior High School in Sibolga. The implementation of inclusive PAI which is the problem in this research is the planning, implementation and evaluation of inclusive PAI in Senior High School in Sibolga. The research method in this research is qualitative research with a phonomenology approach, namely analyzing the factors of inclusive Islamic education at State Senior High School in Sibolga. Based on the findings in this study, it can be concluded that the implementation of inclusive Islamic Education in the Sibolga City Senior High School includes planning that includes the school's vision and mission, school work programs/PAI teachers, curriculum, ex-kul, methods, related activities. Based on the results of the evaluation in this implementation, it can be seen that inclusive PAI has the support of school residents and builds inclusive school residents.
\end{abstract}

Keywords: pai; inclusive; state senior high school; sibolga;

\section{Introduction}

Islamic teachings really appreciate differences and even these differences are a necessity. Thus, in the context of Indonesia in particular, diversity is a wealth that is owned and even this diversity is very rarely found in other countries in the world. Specifically in the field of religion, in this case Islamic religious education provides a positive contribution by providing multiculturalism nuanced knowledge based on how a humanist and pluralist individual lives. This is stated clearly in QS Al Hujarat 49:13:

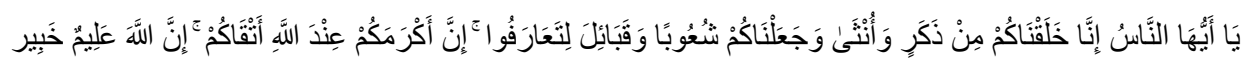

Meaning: O people, we actually created you from a man and a woman and made you nations and tribes so that you would know each other. Indeed, the most noble among you with Allah is the most devout among you. Allah is Allknowing, Most-Knowing.

The verse Shihab (2012: 615) explains about the basic principles of human relations in social life, therefore this verse no longer uses a call addressed to believers, but to human types. This affirms that all humans with the same human degree in the sight of Allah, there is no difference between one tribe and another. There is also no difference in human values between men and women because all are created from a man and a woman. It is not natural for someone to be proud and feel themselves superior to others, not only between one nation, ethnicity, or skin color and others, but between their genders. The stronger the recognition of one party to the other, the more opportunities are opened for mutual benefit. Therefore, the above verse emphasizes the need to get to know each other. The introduction is needed to draw lessons from each other and the experiences of others in order to increase piety to Allah SWT whose impact is reflected in the peace and welfare of worldly life and spiritual happiness.

Human life will be more beautiful if it is full of color, this is the case when Allah SWT creating humans in one group or one people only, then the world will feel empty and will not be as beautiful as it is today. This is justice from Allah SWT. The problem that then arises when God wants that distinction lies in the difference in religion and differences in the way of life. Indonesia is one of the largest multicultural countries in the world, this diversity is due to its diverse and extensive socio-cultural and geographical conditions (Yaqin, 2005: 4). Data for 2019 shows that Indonesia has a total of around 17,504 islands consisting of large 
and small islands with a population of more than 200 million. Based on these islands, Indonesia has 300 tribes using nearly 200 different languages, the largest ethnic group in Indonesia is the Javanese with a total of $40.2 \%$, Sundanese (15.5\%), and the Batak ethnic group (3.58). \%), Madurese (3.03\%), Betawi 2.88\%), Minangkabau (2.73\%), Bugis (2.69\%), Malays (2.27\%), Arab ethnic groups (2, 10\%), Banten (1.97\%), Banjar $(1.74 \%)$, Balinese (1.67\%), Sasak (1.34\%), Dayak (1.27\%), Chinese (1.20\%), Makassarese (1.13\%), Cirebonese $(0.79 \%)$. Indonesia also has religious diversity, with the existence of these religions playing an important role and contributing to people's lives.

Geographically, the city of Sibolga is one of the cities that has been living side by side with multiethnicities and religions. The ethnic groups consist of Batak, Mandailing, Minang, Nias, Javanese, Minahasa, Dayak, Bugis, and Sundanese, Arabic and Chinese tribes. Also religious plurality consisting of Islam $(57.39 \%)$, Protestant $(34.57 \%)$, Catholic $(5.08 \%)$, and Buddhism $(2.94 \%)$. With this diversity, it has become part of the responsibility for Islamic Religious Education teachers to deliver inclusive Islamic education to students, of course with a good understanding of inclusive education itself. With this understanding, religious diversity in Sibolga has been maintained. Based on this explanation, the diversity of the Sibolga community is unique in itself, this is because with this diversity the Sibolga people live in harmony. Although there are several incidents that have occurred in the community, the issue of religion has not been raised, of course this cannot be separated from the implementation of inclusive-based education in the city of Sibolga. One example of the incident occurred when the bombing in Sibolga on March 13, 2019, shocked various parties, but religious harmony was maintained. The bomb incident did not raise religious issues, but rather aimed at the perpetrators.

Based on this, the consideration in this study is to conduct a more in-depth study of inclusive education and its implications for PAI State Senior High School in Sibolga teachers. On the other hand, Azra provided an analysis of the occurrence of a suicide bombing at the Medan Police on November 3, 2019, it was necessary to have a concept that could tackle these acts of terrorism. This incident provided an offer by Azra that one of the solutions offered was to implement Islamic values based on context. The point is, Islam does not look at only Muslims who are in one area but Islam is in diversity by conveying the mission of peace and brotherhood.

Based on the aspect of implementing the values of inclusive education, at State Senior High School in Sibolga it has even become a culture. This can be seen from the familiarity of students in school activities, both in the learning process and outside study hours. At the time of the birthday of the Prophet Muhammad. For example. All students take part and help each other in preparing for the maulid activity. During the maulid activity, all students, teachers, and parents of guardians were present even though they were nonMuslims. It can be seen that there is an atmosphere of harmony within the frame of diversity at State Senior High School in Sibolga. Based on this explanation, this study describes the implementation of inclusive PAI in State Senior High School in Sibolga.

\section{Research Method}

This research was conducted at Senior High School in Sibolga which consisted of 4 schools, namely State Senior High School 1 Sibolga, State Senior High School 2 Sibolga, State Senior High School 3 Sibolga, and State Senior High School 4 Sibolga. While the implementation time was carried out in the even semester of the 2019/2020 academic year. The research method used in this research is qualitative in which data interpretation uses descriptive analysis. Descriptive research is not intended to test certain hypotheses, but only describes what it is about a variable, symptom or situation in the field (Arikunto, 1998: 315). Based on this, this research is not intended to find a new theory, but researchers only want to describe a social phenomenon or a social environment consisting of places, actors, and activities so that a standard concept can be found that can be used as a science.

This research takes place in a natural setting that requires the presence of researchers in the field, therefore researchers make observations by visiting research subjects or informants directly (face to face) by visiting the research location that the author wants to examine. With the presence of researchers in the field as a research instrument, its function is that the subject is more responsive to the presence of researchers. The data used in this study consisted of two types, namely primary data and secondary data. This study uses a phenomenological approach, thus what researchers do to extract information from the subject, such as the subject's experience, the meanings of the subject's experience. Information from the subject can increase the knowledge and insight of the researcher, so that the researcher can develop his ability to manage research results as an important science. Based on the explanation above, the instruments for collecting data in this study are observations, interviews, documents and field notes.

Testing the validity of data in qualitative research only emphasizes validity and reliability, because in qualitative research the main criteria for research data are valid, reliable, and objective. Techniques for 
checking the validity of data are participation extension, observational persistence, triangulation, peer checking, referential adequacy, member checking, detailed description, dependency audits, and assurance audits. The data validity checking technique used in this study only used three techniques, including: participation extension, observation persistence and triangulation.

\section{Results and Discussion}

\section{Implementation of Inclusive PAI at Senior High School in Sibolga}

\subsection{Planning}

The concept of the highest goal of Islamic education is not only theoretically oriented, but runs a balance between theoretical and practical. So that in essence the purpose of Islamic education does not separate faith and righteous deeds. The educational goals to be achieved by reading, purifying, and teaching as mentioned in the verse are the same as devotion to Allah. In other words, Islamic education is philosophically oriented towards Islamic values targeting three dimensions of human relations as caliph on earth, namely as follows;

1. Cultivating a balanced and harmonious relationship with God,

2. Forming a harmonious, harmonious and balanced relationship with the community,

3. Developing the ability to explore, manage, and utilize natural resources for the benefit of their welfare and the lives of others as well as for their ubudiyah interests to Allah SWT. Based on a harmonious attitude as well

So in this case, based on the description above, there are at least five things that can be informed about how inclusive Islamic Education learning includes them:

1. Inclusive PAI learning must create and maintain educational institutions and educational environments that are tolerant and respect differences;

2. Inclusive PAI learning integrates the curriculum

3. Inclusive learning plays a role in encouraging teachers to teach interactive;

4. Inclusive learning encourages teachers and their classes continuously and removes barriers related to professional isolation, and

5. Inclusive learning means involving parents, stakeholders, and the school environment in a meaningful way in the conversation process.

PAI learning at State Senior High School in Sibolga in realizing inclusive learning is inseparable from the vision and mission of State Senior High School in Sibolga. All State Senior High School in Sibolga continue to emphasize a vision with a cultural or environmental perspective with the aim of respecting differences. For example, State Senior High School 1 Sibolga, the vision of State Senior High School 1 Sibolga is the realization of students who are smart, accomplished, have faith and culture and have an environmental perspective. Meanwhile, the mission of State Senior High School 1 Sibolga is:

1. Increasing the quality of learning and extra-curricular activities based on faith and piety as well as good culture and discipline

2. Improve the quality and function as well as the utilization of learning facilities and infrastructure as well as learning and other learning resources

3. Establish good and harmonious cooperation between school members, communities and related agencies

Sewhereas the vision of State Senior High School 2 Sibolga is to excel in achievement, have a noble character, have a polite culture, and be conducive in a beautiful environment. Through this vision, it is realized through the following mission:

1. Carry out an optimal learning process

2. Develop teaching materials continuously and in line with current needs

3. Develop various information and communication technology infrastructure for learning activities, school administration, and internal/external communication

4. Developing libraries as learning media and providing complete information

5. Fostering the spirit of achievement in all school members

6. Carry out student development through extracurricular activities

7. Carry out religious activities in the school environment in the daily life of the school community

8. Fostering a sense of pride as a school member

9. Cultivate a healthy, clean, beautiful, pleasant environmentally friendly lifestyle

10. The realization of the 3P culture (appearance, service and achievement).

Based on this vision and mission, PAI teachers align with the goals of inclusive PAI learning so that in the end graduates from State Senior High School still respect differences and are smart. Differentiation of assistance or intervention given needs to be seen as an effort to provide educational services provided and 
not seen as an attempt to separate students from diversity into homogeneity. For this reason, in implementing inclusive PAI education, at least the following matters need to be considered:

1. Listing students based on ethnicity, religion and ethnicity so that they can be harmonized with the Islamic Education curriculum

2. Knowing the needs of students

3. Determine the learning strategy

4. Evaluate and monitor student progress

By knowing the concepts and learning strategies in inclusive learning can accommodate the needs of students to be able to interact with other students so in this case it can be seen that, in State Senior High School PAI teachers in particular have the flexibility in the learning process with the control of inclusive education to provide warm classroom conditions friendly, accepting diversity and respecting differences, conducting heterogeneous class management by applying curriculum and individual learning, implementing interactive learning.

Based on this explanation, the first function of planning management is the first step that must be taken. Educational planning is a rational application of systematic analysis of the process of educational development with the aim that education is more effective and efficient and in accordance with the needs and goals of students and society. As it is understood, inclusive Islamic religious education cannot stand alone without other accompanying factors. So to realize the goals of inclusive PAI in activities both in the learning process and outside of learning are not only limited to planned learning activities but must also accompany other factors that participate in the educational process. At the beginning of the school year at State Senior High School in Sibolga, planning for inclusive Islamic religious education for the next year is determined by the syllabus and curriculum and learning targets outside the curriculum that will be focused on being inclusive. The principal as the beginning of the school year provides direction to all teachers to still respect differences.

Based on this, the differentiation of the interventions provided needs to be seen as an effort to provide the education services provided and not seen as an attempt to separate students from diversity to become homogeneous. So as for the planning in inclusive PAI is:

1. Listing students based on ethnicity, religion and ethnicity so that they can be harmonized with the Islamic Education curriculum

2. Knowing the needs of students

3. Determine the learning strategy

4. Evaluate and monitor student progress

In order to make inclusive learning a culture or climate in State Senior High School in Sibolga, continuous evaluation is carried out. PAI education is carried out independently by PAI teachers through the learning process and outside the learning process. PAI teachers carry out the learning process by integrating inclusive values in the learning process with strategies that are in accordance with the material being taught. Meanwhile, evaluation is not different from other evaluations but only emphasizes the affective aspect because inclusive values emphasize more on practice.

In the life of State Senior High School in Sibolga which is a pluralistic style of school community life, in this case the cultivation of spiritual values with inclusive colors will shape the spiritual intelligence of students to be good. The intelligence of these students will give its own contribution to all events in students' lives in a plural school environment. So it needs to be understood that the characteristics of inclusive Islamic education that have spiritual intelligence are doing good, helping, empathizing, forgiving, having happiness, and feeling that they have a noble mission in life. Inclusive PAI values integrated into the learning process will shape students to have self-awareness, spontaneity, internally motivated, compassionate, respect diversity and be independent so that it will bring out a strong student personality and a sense of respect for differences.

\subsection{Implementation}

Basically, students are very much determined by the values that are actually lived as a guide for their attitudes and behavior, both in their relationship with themselves and Allah, the social life of the community and the natural surroundings. These behavioral tendencies are related to inclusive values, so these values can sharpen the quality of the spiritual intelligence of students so as to form good morals for the students themselves. So in this case, all school members with the values of spirituality itself are objectified into the learning process. The spiritual values in question are honesty, justice, virtue, togetherness, and social solidarity, where these values are part of the implementation of the values of moral education. These good values are the highest level of the goals of inclusive Islamic education, so in its implementation the better the students are in these values, the better the quality of their spiritual and emotional intelligence will be. 
The implementation of inclusive PAI generally faced by PAI teachers in realizing inclusive Islamic religious education faces three main challenges, namely religion, ethnicity, and tradition, belief, and tolerance. The strength of this antagonistic discourse indicates that differences in religion, ethnicity and tradition are still prone to causing mutual suspicion and mutual feeling of being threatened by one another which then encourages tension, acts of violence, deception and acts of terror. One of the efforts to create a harmonious relationship is through inclusive education activities, namely educational activities in order to develop the wisdom of understanding, awareness, attitudes, and behavior (mode of action) of students regarding the diversity of religions, cultures and society. This is what State Senior High School in Sibolga has built by working together to support especially Islamic Education teachers in this inclusive implementation. If there is no cooperation and openness of PAI teachers at State Senior High School in Sibolga, of course, to realize inclusive Islamic Education will be an obstacle as previously explained.

So based on this, it is necessary to reform the curriculum that was formed by PAI teachers because there is no standard curriculum on inclusive PAI. Inclusive Islamic religious education aims to strengthen each other's religious beliefs and practice religious teachings in life. At the same time, emphasizing the appreciation of social values that originate from religion and encouraging tolerance and mutual respect among followers of different religions, as well as cooperation in solving problems in various aspects of life as a form of practicing religious teachings. Thus, inclusive Islamic religious education respects the diversity of religions, cultures, ethnicities and languages while still adhering to the principles of their respective religions. The efforts made to give birth to this concept were made through the existing Islamic religious education curriculum. So in this case, it is necessary to reinterpret the existing holy texts as a manifestation of religious concern for social reality.

In the context of inclusive Islamic religious education, it is the transformation and internalization of the basic values and ideals of Islamic teachings that seek to accentuate aspects of differences and disparities in humanity in its broad context as a grand design of God that must be accepted wisely and gracefully in the midst of reality. Plural humanity in all its dimensions in order to create a just life order (mardhati Allah). So in this case, inclusive Islamic religious education is a comprehensive effort in preventing conflicts between religions, preventing religious radicalism, while at the same time fostering a positive appreciative attitude towards plurality in any dimension and perspective. So, the vision and mission of the school remains in line with the objectives of PAI, namely to realize religion in a more polite, dialogical, appreciative side to plurality and care for transformative communal life problems for students.

So in this case, the PAI curriculum at State Senior High School in Sibolga as a whole has formed a concept of an inclusive Islamic religious education curriculum that answers the challenges of an increasingly complex and dynamic era. So that inclusive PAI covers the shortcomings that are the basic character of existing Islamic religious education. Among the gaps or shortcomings of Islamic religious education in its custom in educational institutions is that religious education places too much emphasis on cognitive and rote aspects. In the end, students may be able to answer all PAI subject exams, but it has no impact at all on changes in daily behavior. This is an emphasis at State Senior High School in Sibolga in PAI learning, in PAI learning in Sibolga is something that really emphasizes the social life of students. Living in a pluralistic society, if it is emphasized on the textual teachings of Islam, will foster divisions in society. Islamic religious education needs to emphasize the attitude of life, moral values and appreciation of life that can help children develop their lives in a better direction. So for now, the Islamic religious education model must keep the teachings conveyed not emphasizing indoctrination which requires acting strictly on one choice.

Based on this explanation, Islamic religious education materials do not tend to emphasize formal worship and are ritualistic and do not lead to appreciation in the social aspect. The PAI curriculum at State Senior High School in Sibolga really maintains the teaching which has an impact on the formation of a very pious personality in matters of ritual worship but not in the dimensions of social piety. More precisely it can be said that students are less sensitive to fate, suffering, difficulties experienced by others. This paradigm is that State Senior High School in Sibolga really maintains an inclusive life, so there are several important things to put forward in terms of the inclusive Islamic religious education curriculum at State Senior High School in Sibolga, namely:

1. Inclusive Islamic religious education includes an unwritten curriculum dimension that seeks to integrate the learning process of values, knowledge and life skills in a diverse society.

2. An inclusive Islamic religious education curriculum is presented using more than one perspective regarding historical events and phenomena of life.

3. Inclusive Islamic religious education needs to be directed so that it is educated to understand Islamic doctrines completely and comprehensively and not to dwell on ritual issues or prioritize a mere fiqhiyah approach.

4. The inclusive Islamic religious education curriculum accentuates without neglecting theological values in the formation of moral values, such as love, help, tolerance, tolerance, and respect for differences. 
5. The transformation of inclusive Islamic religious education must refer to and be based on a learning pattern that ensures all student diversity in all its aspects which results in interactive learning patterns that are student oriented.

Based on this description, the inclusive Islamic religious education curriculum is dynamic, in the sense that it constantly demands renewal, innovation or reorientation of curriculum components in accordance with community dynamics and developments in situations and conditions. This can be emphasized that there is no patent model or standard form in its formulation, so it can be emphasized that the construction and composition of the content of the inclusive Islamic religious education curriculum is contextually dynamic. Principal of State Senior High School and PAI teacher of State Senior High School in Sibolga explained that there are no standard rules and standard curriculum for inclusive PAI. But only formed in an unwritten rule but a rule that must be obeyed.

Based on this explanation, PAI is inclusive in conveying inclusive values not only in the learning process. In addition to the curriculum, syllabus, methods that direct inclusive PAI, PAI teachers also involve the school community in affirming and reinforcing that PAI not only regulates relationships among Muslims but teaches life mingling with various differences. This is realized by involving all students and teachers in religious activities. On the other hand, PAI teachers also invite students to participate with their friends of different religions or their teachers in various activities. So the role of PAI teachers in the school environment is to strengthen the relationship between students and school members, with this role the PAI teacher becomes a place to solve religious problems of school residents. Then this will affect the strategy to build an inclusive culture so that coexistence becomes a family. Islam is very concerned about ethics and tolerance in education, the goal is that Islamic education can build intelligence in various aspects of education and become enlightened for society. And it is known that the community is a collection of various ethnicities and tribes and religions. The intelligence is intellectual intelligence, emotional intelligence and spiritual intelligence and the three intelligences must be able to integrate inclusive values. This shows that Islamic education highly upholds ethics and human values, with an inclusive concept in maintaining mutual respect. It is hoped that education will produce universally intelligent students both intellectually, emotionally and spiritually. Islamic education takes this very seriously, this can be seen by the concept of a regulated concept relating to the rights and obligations of students and lecturers. Science in Islamic life is a very important and fundamental thing, but the most important thing is adab so that it will have a good impact so that the achievement of the goals of education itself.

The potential possessed by humans themselves, to face nature, always strives to be side by side with nature itself, even though some humans with the potential that this nature possesses are damaged. But on the other hand it can be seen that with this thought process, humans have already philosophized. In accordance with the foundation used, the ideas from these thoughts are made in one concept and outlined in a rule called education. This is where the PAI teacher's role is to instill inclusive values with ideas based on the Koran and hadith, so that the inclusive style that is carried out has its own color. So in this case, especially the principal of State Senior High School in Sibolga gives freedom to all school members to participate in Islamic religious activities, but what is unique is that when non-Islamic religious activities, Islamic students do not participate. This is not a problem by the school community and they understand about it. Here it is seen that the PAI teacher has been able to develop an inclusive concept with an Islamic style. Based on interviews with several students of State Senior High School in Sibolga, during the New Year they provide food and bottled drinks because they know that the food served is not eaten. Meanwhile, when Eid they also come and eat the food that is served. Here it can be seen that students live in tolerance and respect and have become a culture to maintain brotherhood and are limited by Islamic values.

\subsection{Evaluation}

Inclusive Islamic education has an openness that is manifested in culture and scientific insights that will bring Muslims in an Islamic civilization to a very high level. Thus Islamic education emphasizes Islamic education as social ethics in social life. The correct Islamic education concept must teach the formalization of Islam in accordance with the contextual existence of Islam in society. It cannot be denied that the fact of Islamic modernization was shaped by the long history of Indonesian Islam. Lack of knowledge about the dynamics of the realities of life in a pluralistic society and the absence of acknowledgment of the influence that these dynamics can have on the understanding and application of the messages of holy texts constitute great potential for radical Islamic understanding and behavior and of course a great challenge for their growth and development. Moderation in Islam. It has been explained earlier that Senior High School in Sibolga, in the context of Inclusive Islamic education, does not become a standard written rule. But in the implementation of inclusive education, the values of inclusive education are implemented in the learning process and various activities in schools. 
Inclusive PAI is not stagnant with the learning that is faced individually, but continues to develop along with the progress of society, various forms of activities and the development of inclusive teaching materials in schools in particular so that it becomes an inclusive culture. This subjective reality continues to be internalized in everyday life, because being inclusive has a very broad meaning, so that it can be internalized in every second and space of a student's life. Besides that, it also establishes intense communication, has a friendly attitude with the community, respects opinions, appreciates the weaknesses and strengths of each, until finally also becomes more sensitive to what is the problem that exists in the community to immediately get a solution.

Based on this, in order for inclusive PAI to become a standardized culture, evaluations are needed so that the implementation is not stagnant. Basically, evaluation of systematic collection of facts to determine whether in reality there has been a change in students and determine the extent to which the level of change in the student's personality. The concept of evaluation is inseparable from a process for planning, obtaining, and providing indispensable information to make several alternatives in making decisions. Evaluation activities are carried out to obtain information or data; based on these data then try to make a decision. Where the data information collected must be data that is appropriate and supports the planned evaluation objectives. So that evaluation is absolutely necessary in a learning process, as well as the implementation of moral education values both in the learning process and in academic services. So based on this, the objective for evaluation in inclusive PAI is to assess the benchmarks for the success or failure of the implementation of inclusive PAI so that weaknesses and appropriate improvements are obtained. So with the evaluation in this activity, it can be seen what needs to be improved, corrected, considered sufficient/lacking, so in simple terms it can be said that without evaluation we do not know the progress/setbacks that have occurred.

Implementation of inclusive PAI at State Senior High School in Sibolga evaluation is needed in reviewing what happened before, the obstacles, the problems faced, how far the understanding of the material provided was. Then conclude whether the activities that have been carried out are successful or fail, this means that without evaluation, the results of the implementation of the values of inclusive Islamic religious education at State Senior High School in Sibolga will not be known. This was said by the principal of State Senior High School 3 Sibolga that the evaluation process carried out at State Senior High School in Sibolga in the implementation of inclusive PAI, especially those that had been determined whether the implementation of learning was good, and various activities were carried out every week, not semester or annually through teacher meeting activities. The evaluation carried out was not written, but the PAI teacher's report on the implementation of learning and the obstacles faced. So, every obstacle and program progress is evaluated every week, while to revise programs that are constrained or if there is a program being developed, it is carried out at the end of each semester. While the implementation mechanism is controlled by the principal, deputy principal and the teacher concerned.

Based on this explanation, it is clear that the evaluation of the implementation of inclusive PAI is generally carried out by the principal on a weekly basis, while the programs that need to be revised will be standardized at the beginning of each semester. Whereas for PAI teachers at State Senior High School in Sibolga, the evaluation was carried out independently and in a structured manner and the improvements made as an independent reference by the PAI teacher were both for revising learning programs and developing programs so that the programs carried out always developed according to the needs of students. Basically, in the journey and growth of a region's education that freedom as a modern concept is not inherited, but is captured and digested through the learning process, therefore, to understand it, a process of education is needed (Winataputra, 2006: 19). It seems that this concept was developed by PAI teachers at State Senior High School in Sibolga, it can be said that this is different from the other inherited decisionmaking models even though the policies carried out are influenced by a group. So, the implementation of the evaluation developed by PAI State Senior High School in Sibolga teachers used the concept of freedom.

It cannot be denied that freedom is a need of many people, so in the direction of changing the ideal educational institution is not easy because the process of implementing this program is a strategic system in inclusive life carried out at State Senior High School in Sibolga. So it is in this context that the strategic system adopted by Islamic Education teachers is to adopt a system of protecting all groups with various things that are diverse without seeing one eye or a group. So in this case, PAI is inclusive not only in learning but in various activities involving the State Senior High School in Sibolga school community. Based on this, it can be seen that the evaluation attitude of PAI State Senior High School in Sibolga teachers is as follows:

1. A process that takes place will be continuous continuously.

2. Disifati with the concept of stages.

3. Changes made are peaceful by carrying out the mission of rahmatal li al 'alamin.

4. Every regulation that is carried out is resolved by way of deliberation. 
Basically, PAI teachers in implementing inclusive PAI invite to hold an attitude of tolerance in carrying out a policy or building student morals. So, using the concept of inclusion in the implementation of Islamic religious education in order to accept the social and cultural pluralism that really exists in society. So in this case, an inclusive and tolerant religious attitude is demanded in various aspects of implementing campus programs. This is very necessary for an appropriate attitude to respond to this diversity expressed by the values of moral education developed in Islamic Education teachers at State Senior High School in Sibolga, namely spiritual values, honesty values and tolerance values. This is what makes the evaluation carried out does not seem unsuccessful but provides an understanding that each program needs to be developed so that it can provide needs for students according to community needs.

The formalization of Islamic teachings is not part of that transformation, but they contribute to the formation of a society in which Muslims can implement themselves individually or socially as a social ethic. This is what is integrated in the environment of State Senior High School in Sibolga, with this strategy Islam is accepted and is not used as a material for separation, but problems are seen from the perpetrators. In the social strategy, Islamic education, especially Islamic education teachers and Muslim students at State Senior High School in Sibolga, does not rule out the conditions and developments of the times that continue to evolve. Sociocultural strategies are also very much needed in Islamic education to form diverse ways of thinking, because of the condition of the nation consisting of various ethnicities, ethnicities and religions.

\section{Conclusion}

Based on the findings in this study, it can be concluded that the implementation of inclusive Islamic Education in the Sibolga City Senior High School includes planning that includes the school's vision and mission, school work programs/PAI teachers, curriculum, ex-kul, methods, related activities. Based on the results of the evaluation in this implementation, it can be seen that inclusive PAI has the support of school residents and builds inclusive school residents.

\section{References}

Azra, Azzumardi. (2019). Menganggulangi Terorisme (Countering Terrorism) in Harian Kompas, 21 November 2019.

Arikunto, Suharsimi. (2010). Manajemen Penelitian (Research Management), Jakarta: Rineka Cipta.

https://Sibolga.bps.go.id/ publication/2010, accessed on 06-07-2019.

https://www.kemendagri.go.id, accssed on 19-05-2019.

https://www.bps.go.id/sp 2010, accssed on 19-05-2019.

Shihab, M. Quraish. (2006). Tafir Al-Misbah, volume 2, Lentera Hati, Jakarta.

Winataputra, U.S. (2006). Demokrasi dan Pendidikan Demokrasi (Democracy and Democracy Education), Jakarta: Ditnaga Dirjen Dikti.

Yaqin, Ainul, (2005). Pendidikan Multikultural; Cross-Cultural Understanding untuk Demokrasi dan Keadilan (Multicultural Education; Cross-Cultural Understanding for Democracy and Justice), Yogyakarta: Pilar Media. 